\title{
Multistakeholder governance processes as production sites: enhanced cooperation "in the making"
}

\author{
Julia Pohle \\ Berlin Social Science Center (WZB), Germany \\ Published on 30 Sep 2016 | DOI: 10.14763/2016.3.432
}

\begin{abstract}
The paper combines actor-network theory and interpretative policy analysis to conceptualise multistakeholder arrangements in internet governance as production sites in which heterogeneous actors engage in dynamic processes of social ordering such as shared meaning-making and coalition building. The paper draws on existing research that traces processes of social ordering at the intersection of multistakeholder settings and intergovernmental institutions, and on theoretical considerations of multistakeholder mechanisms in internet governance. By focusing on processes of discursive production, the paper adds a new perspective to the existing body of literature on science and technology studies and internet governance, and provides illustrations based on deliberations of the Working Group on Enhanced Cooperation.
\end{abstract}

Keywords: Actor-Network Theory, Interpretative Policy Analysis, Hybrid space, Discourse, Black box

\section{Article information}

Received: 05 May 2016 Reviewed: 12 Jun 2016 Published: 30 Sep 2016

Licence: Creative Commons Attribution 3.0 Germany

Competing interests: The author has declared that no competing interests exist that have influenced the text.

URL:

http://policyreview.info/articles/analysis/multistakeholder-governance-processes-production-sites-enh anced-cooperation-making

Citation: Pohle, J. (2016). Multistakeholder governance processes as production sites: enhanced cooperation "in the making" . Internet Policy Review, 5(3). https://doi.org/10.14763/2016.3.432

This paper is part of Doing internet governance, a special issue of Internet Policy Review guest-edited by Dmitry Epstein, Christian Katzenbach, and Francesca Musiani.

\section{INTRODUCTION}

The last decade witnessed rapidly growing interest among scholars from different disciplines in the new forms of participatory governance and multistakeholder deliberation that have emerged around the coordination and regulation of the internet. Most scholarly research examines these 
new forms by focusing on institutions of internet governance, the role and interests of stakeholders and their influence on the output of policy debates. Less common are analyses centring on the interactions and processes of multistakeholder governance, aiming to assess what is actually happening inside the black box of the newly created institutions and their complex deliberation and coordination mechanisms (Epstein, 2013; Flyverbom, 2010; Gasser, Budish, \& West, 2015).

Using the toolbox provided by science and technology studies (STS) this research paper seeks to contribute to the second stream of scholarly work by exploring the inner workings of multistakeholder arrangements in the field of internet governance (IG). The work builds on existing research that traces processes of social ordering at the intersection of multistakeholder settings and intergovernmental institutions (Epstein, 2012; Flyverbom, 2011) and on theoretical considerations of multistakeholder and coordination mechanisms in IG (Hofmann, 2016; Hofmann, Katzenbach, \& Gollatz, 2016). The paper adds a new perspective to the existing literature because it focuses primarily on processes of discursive production in internet governance. By combining concepts of actor-network theory (ANT) and interpretative policy analysis (IPA), the work explores how actors translate ideas, shape meaning and compete over the inscription of discourse into policy outcome. By framing the discursive struggles in IG policy processes as vying for power and influence, the paper seeks to open the black box of multistakeholder policymaking and to apply the conceptual instruments of ANT and IPA to retrace how actors position themselves within discursive production processes. By focusing on processes rather than outcomes, it is possible to identify how and which actors are able to exert influence and to show that, despite a lack of binding policy outcomes, multistakeholder arrangements in IG can produce valid results.

Once the conceptual ideas have been introduced and the theoretical challenges discussed, these are illustrated, using selected and emblematic examples from recent deliberations within the UN Working Group on Enhanced Cooperation (WGEC). The objective of this multistakeholder group was to overcome controversies on the role of governments in IG, which have persisted since the World Summit on the Information Society (WSIS). With its aim of inscribing meaning into the discursive artefact of "enhanced cooperation" (a diplomatic term introduced in IG by the WSIS outcome document in 2005), the WGEC lends itself particularly well to an empirical analysis which, rather than centring on policy outcome, concentrates on unravelling the processes of discursive interaction within a restricted network of actors. 1 The empirical research builds on desk research, online observation, document analysis and interviews with some of the WGEC's members and observers, conducted in 2014. Beyond the presentation of empirical examples, the main objective of this paper is to introduce the conceptual marriage between ANT and IPA and, in so doing, it is hoped to contribute qualitatively and significantly to the existing body of literature on STS and IG. In its concluding section, the paper discusses the conceptual notions introduced earlier, in light of the frequent criticism that multistakeholder arrangements are unproductive.

\section{STS IN INTERNET GOVERNANCE: RETRACING PROCESSES OF DISCURSIVE PRODUCTION}

The recent interest in integrating concepts and tools from STS into the theoretical and empirical research on internet governance has resulted primarily in a focus on the internet's materiality and the complex practices through which actors shape and use the internet infrastructure for 
governance purposes (DeNardis, 2014; Musiani, 2015; Musiani, Cogburn, DeNardis, \& Levinson, 2015). While equally drawing on STS literature, the aim of this short research piece is to open another of the many black boxes 2 of internet governance by exploring the performative effects of multistakeholder deliberations and the conflictual co-production of discourse in policy debates. To this end, the paper proposes to combine selected tools from actor-network theory with interpretative policy analysis, another tradition which, with some notable exceptions (Epstein, 2011, 2012; Pickard, 2007), is still underrepresented in IG research.

In keeping with IPA, the underlying assumption of this paper is the conception of policymaking as "a constant discursive struggle" (Fischer \& Forester, 1993, p. 2) as well as the understanding that, more than anything else, it is the ideas and language exchanged in policy debates that shape the definition of policy problems and their solutions (Fischer, 2003; Fischer \& Gottweis, 2012). Accordingly, interpretative analyses are marked by a focus on policy discourse and its creation through the meaning-making capacities of actors involved in policymaking. Yet, IPA goes beyond a static or purely linguistic understanding of "discourse" 3 and, instead, proposes to study its importance for policymaking by assessing processes of "arguing" and the exchanges between actors in policy debates rather than the language of the final outcome documents (Hajer, 1993, 2002; Münch, 2016). 4

To construe policymaking as a struggle over and a process of meaning-making implies three important consequences for policy research: first, it moves policy analysis away from its established teleological perspective. What is of greatest interest is not the input and output of policymaking and their causal interrelation, but rather the processes of policymaking, including all deliberations, negotiations, and decision-making. Second, IPA not only assesses the language or ideas of the actors involved in policy debates, but also the actors themselves, their social practices and their interactions. Hence, interpretative approaches add the aspect of "agency" to the analysis of discourse; in other words, they attempt to "reintegrate the subject" into the study of policy (Zittoun, 2009, p. 67). Third, since IPA regards policy as "the outcome of joint productions of meanings among various policy actors [emphasis added]" (Mottier, 2005, p. 256), it concerns the interactions of actors in the policy process and, accordingly, assesses how various actors, jointly but antagonistically (Marres, 2007, p. 773), engage in meaning-making and the production of common discourse, during policy debates.

When combining these three aspects, researchers interested in meaning-making in IG and elsewhere need to consider not only the arguments exchanged during policy debates, but also the actors, their practices and the dynamic (power) relations between them. Vivien Schmidt interprets this as a departure from a purely postmodernist understanding of discourse in which only the content of ideas has a centre stage position. By focusing on the actual processes of arguing and discussing, the creation and origins of the ideas thus produced as well as the material reality outside of the linguistic utterances are reintegrated into the analysis (Schmidt, 2008, p. 305). Given this relational focus and the interest in the materiality of policy debates, it is surprising that IPA has not been combined more often with ANT, an approach developed for analysing complex processes of co-creation in science and technology (Callon, 1986; Latour \& Callon, 1981). 5 Despite many conceptual and methodological differences, ANT shares IPA's focus on social ordering and the relational production of semantics and materials, and concurs with regard to the three important aspects of IPA mentioned above. But unlike discourse analysis, ANT also provides the tools for retracing production processes on the micro-level. 6

A shared interest of both approaches is to observe processes rather than outcomes. Since ANTinspired research is interested in how relations are established, it considers analysis of actions to 
be a more fruitful path than static situational observation. Accordingly, ANT research focusses on production processes as a way to view an object or meaning "in the making" (Latour, 1993, p. 265). Further, ANT concurs with IPA in its emphasis on actors and their interactions. Seeking to rigorously "follow the actor", ANT attempts to map various elements of the creation process, as well as actors' behaviour and interactions (Law \& Callon, 1988, p. 285). Lastly, ANT overlaps with and, at the same time, goes beyond interpretative approaches in its objective to thoroughly assess the concrete ways through which social order is created contingent on the relationship between actors.

ANT observes the dynamic processes of social ordering by focusing attention on what it calls "translations", meaning the interactions through which actors build relations, influence each other and the objects they produce. 7 When combined with a focus on discursive production, the ANT term "translation" refers to all processes of deliberation, negotiations, and intrigues, which allow actors to construct common definitions or narratives and build coalitions. Since it is through these efforts that actors mobilise other actors to share their political, social, cultural or economic interests, the process of translation can be considered as the creation of alignment in interest (Rutland \& Aylett, 2008, p. 635). Hence, by following closely the actors and their translation processes, the combination of IPA and ANT makes it possible to better understand the "plurality of processes, formal and informal, where actors, with different degrees of power and autonomy, intervene" (Raboy \& Padovani, 2010, p. 151) and thus to unravel the often chaotic and irrational internal workings inside the black box of policy deliberations in IG.

Despite the fruitful correlations between ANT and IPA, the two approaches differ with regards to some underlying epistemological assumptions. While ANT recognises that discourse can generally have an impact on production processes, it considers discourse as merely one influential element amongst many others. In fact, ANT acknowledges the role of discourse or a linguistic utterance only if it leaves a trace in the policy process that can be observed by the researcher, for instance in the form of a text and/or a detectable shift in the position of other actors. This is in contrast to IPA and similar approaches, for which discourse and language have priority over other influences such as economic interests or material structures. In addition, policy analysis inspired by discourse analytical approaches often draws on Foucault's understanding of discourse, which is strongly connected to the notion of power. Thus, discourse is often considered to simultaneously express, reinforce and reproduce overarching power structures. Conversely, ANT-scholars commonly reject the idea of power structures as external forces which act upon the processes under scrutiny. In ANT, power relations are always contingent, created on the micro-level through the interaction and practices of actors; they only have significance if they leave a trace (Law, 1992, p. 388). Nevertheless, these epistemological differences -whose full exploration would go beyond the scope of this paper- do not preclude the combining of ANT and IPA on a conceptual and empirical level. For the analysis of discursive production in IG, using selected ANT tools allows us to examine concretely how power relations and discourses are created in a multistakeholder context, without needing to consider nor justify them by appealing to external economic forces, political interests or geopolitical tensions. 


\section{OPENING THE BLACK BOX OF DISCURSIVE PRODUCTION IN MULTISTAKEHOLDER ARRANGEMENTS}

Why is the combination of ANT and IPA particularly suitable for studying discursive production processes in multistakeholder arrangements? There are two main reasons for this: first, multistakeholder arrangements are hybrid spaces in which heterogeneous actors engage in processes of social ordering. Second, multistakeholder arrangements - especially in IG - are discursive spaces because they serve primarily as venues for dialogue and coordination.

The "hybrid space" aspect refers to the character of multistakeholder processes per se, which can be defined as governance settings that incorporate "representatives from multiple groups in discussions and decision making" (Gasser et al., 2015, p. 2) - for instance, from governments, the private and technical sector or civil society. 8 From an ANT perspective, these settings are spaces in which heterogeneous actors from different backgrounds, with diverging social practices come together and engage in processes of social ordering (Callon, Lascoumes, \& Barthe, 2009, p. 18; see also Flyverbom, 2011, p. ix). Because of its expanded definition of actors, ANT allows researchers to assess multistakeholder policy processes in a way that differs significantly from traditional policy or institutional analysis, taking the particularities of multistakeholder arrangements into consideration.

In accordance with the ANT principle of "generalised symmetry", the term "actor" does not refer to someone "who wishes to grab power[,] makes a network of allies and extend[s] his power"; rather, it is a semiotic definition comprising many sorts of "actants", all of which can have an observable impact on the processes under consideration (Latour, 1996, p. 374). This makes it possible to account not only for human, but also non-human actors like animals, material objects or technology. It also means that organisational settings, rules and procedures in production processes can be regarded as actors if they affect other actors and influence their practices. This is particularly useful when considering multistakeholder settings in which there are strong relational ties between human actors and material arrangements like the rules of participation, which may be set by the actors themselves and re-negotiated during the processes to which these rules apply. While human actors delineate rules, procedures and organisational settings, these arrangements, in turn, delimit who is allowed to participate. Thus, because the arrangements grant agency to others, this makes them - from an ANT perspective - actors.

By the same token, texts and documents can be considered actors in the processes under scrutiny because they are the result of "a material operation of creating order" (Latour \& Woolgar, 1986, p. 245; see also Nimmo, 2011, pp. 114ff). Multistakeholder processes in IG often contain public consultations and the submission of stakeholder comments in order to include an even larger number of different voices. Moreover, like intergovernmental processes, multistakeholder processes tend to draw on existing policy documents in order to refer to already agreed language. From an ANT perspective, the comments, documents and language do not simply represent input into the processes; rather, they influence the role, position and ideas of actors and, thus, act upon other actors and their endeavours to make meaning. Accordingly, the merit of ANT for studying multistakeholder processes in IG (as well as other fields) is that it allows researchers to consider simultaneously the agency of humans, materials and semiotics as equally important elements in a network of heterogeneous actors. 9 
The second aspect that makes the combination of ANT and interpretative approaches fruitful for IG research concerns the meaning-making capacities of actors and their importance for multistakeholder governance. Both theory and practice suggest that the value of multistakeholder processes in internet governance lies in facilitating dialogue and coordination rather than in producing tangible outcome (Hofmann et al., 2016, pp. 10ff; Pavan, 2012, pp. xxixff). This is prominently visible in the context of the Internet Governance Forum (IGF) which constitutes an emblematic case for the institutionalisation of the multistakeholder policy dialogue in IG. Although there has always been disagreement regarding the exact mandate of the IGF, it is generally understood that the forum should not negotiate policy texts but "ensure an open and inclusive discourse on all policy issues potentially relevant for Internet governance" (Hofmann, 2016, p. 12). 10Therefore, it is possible to conceptualise the IGF and other multistakeholder venues that provide for non-binding policy deliberations as "discursive spaces" (Epstein, 2012, p. 29). ${ }_{11}$ Similarly, Mikkel Flyverbom (2011, p. 167) emphasises the "discursive power" of multistakeholder arrangements and the role of discourses for social ordering, as it is through the production of dominant discourses that some ideas, problem perceptions and policy options become conceivable while others are rendered out of the question.

The combination of ANT and IPA provides the tools for tracing how actors use their own discursive power to contribute to joint meaning-making by translating their ideas and opinions. An actor's translation of an idea or discourse is successful when others adopt it and start to promote the same. 12 But this success is often only temporary. From an ANT perspective, every order is always unstable and precarious and requires continuous reordering so as to be maintained (Latour, 2004, p. 63). One way to stabilise the results of translations for longer periods is to fix them in the most durable material, a process in ANT called "inscription". ${ }_{13}$ In multistakeholder arrangements, inscription occurs, for instance, when a discourse is not simply communicated orally but transformed into a more solid, material form such as written text or -more ideally - an organisational setting or procedure. Through this effort, the discourse becomes institutionalised: "If a discourse solidifies in particular institutional arrangements [...] then we speak of discourse institutionalization" (Hajer, 2005, p. 303). ${ }_{14}$ From an ANT perspective, documents and organisational settings can themselves be actors. Thus, institutionalisations have a strong performative function because the inscribed discourses potentially impact other actors and their production processes. ${ }_{15}$ But even discourse institutionalisations are not permanent because written text can easily be ignored and procedures can be abolished. As a consequence, assessing discursive production in IG through an ANT-inspired perspective implies that we cannot consider institutional structures as given. Instead, the analysis needs to centre on the continuous processes of ordering and reordering through which actors make sense of and build the world around them.

In sum, multistakeholder arrangements in IG can be conceptualised as hybrid sites of discursive production in which heterogeneous actors (including documents and organisational settings) engage in translation processes. During these processes, all actors seek to stabilise their own positions by jointly producing discourse and inscribing it into the materiality of the arrangements. In the following section, the merits of ANT-inspired analyses of discursive production processes in IG are illustrated using empirical examples. The examples used derive from an analysis of the Working Group on Enhanced Cooperation, a multistakeholder group set up by the United Nations, which convened four times in 2013-2014. Because of the conceptual focus of this paper, it is not the intention here to provide the full picture of the group's deliberations and interactions; therefore, the empirical findings are presented selectively. 16 


\section{ENHANCED COOPERATION: A MEDIATOR "IN THE MAKING"}

The multistakeholder concept is related to a large range of approaches and processes in IG. In particular, the IGF and its discursive role have been analysed often and thoroughly. In contrast, much less attention has been paid to "the other track of dialogue created by the WSIS" (Radu \& Chenou, 2014, p. 10), the process of "enhanced cooperation." This second stream of deliberations is particularly interesting for a study that combines an ANT-inspired perspective with IPA since the concept of enhanced cooperation is itself a discursive artefact. The expression is borrowed from European Union Law, where it is used in various treaties to refer "to the coexistence of different rhythms and depths in institutional integration in different policy areas" (Rioux, Adam, \& Company Pérez, 2014, p. 41). In the context of IG, the term was introduced in 2005 in theTunis Agenda, one of the four official outcome documents of WSIS, in an attempt to overcome fundamental discrepancies regarding the role of governments in the technical, operational and policymaking matters of the internet (Brown, 2014; Kleinwächter, 2013).

Inscribed into paragraphs 69 and 71 of the Tunis Agenda, "the process towards enhanced cooperation" was supposed to result in a future mechanism to "enable governments, on equal footing, to carry out their roles and responsibilities, in international public policy issues pertaining to the internet $[. .]$.$" without interfering in the day-to-day technical and operational$ IG matters. By situating the achievement of enhanced cooperation in the future, the documents' authors acknowledged that such a mechanism did not yet exist, nor was there any clearly defined cooperation mechanism that included governments and had an uncontested role with regard to internet policymaking. Thus the concept of enhanced cooperation was a purely discursive artefact which -through its inscription in the Tunis Agenda- gained material form and a durable link to IG. 17

However, the inscription of enhanced cooperation into the Tunis Agenda did not go as far as to specify what the notion meant precisely or how it should be implemented or measured. Since enhanced cooperation was introduced in an attempt to find a compromise, it was left intentionally with a "creative ambiguity" and "much room for interpretation" (Kummer, 2007, p. 9). Therefore, this discursive artefact, enhanced cooperation, can be interpreted as what ANT refers to as a "mediator". Mediators are artefacts produced by actors and circulated during the processes of translation and inscription. They can be immaterial - like services or notions, or material - like texts or other physical objects. It is not their form that makes them mediators, but the fact that they "transform, translate, distort and modify the meaning or the elements they are supposed to carry"; hence, "their input is never a good predictor of their output; their specificity has to be taken into account every time" (Latour, 2005, p. 39).

The actors involved in WSIS recognised immediately that enhanced cooperation was a mediator which could be interpreted in different ways for creating social ordering in IG: "'Enhanced cooperation' is one of the code words in Internet governance discussions and means different things to different people" (Kummer, 2012). During WSIS, some actors - in particular, those from the governmental side - invoked enhanced cooperation to translate their call for more multilateral decision-making in IG through a new organisation under the auspices of the UN, whereas others used it to justify their wish to strengthen the multistakeholder approach. 18 Ever since, translation processes surrounding enhanced cooperation have persisted as actors continuously seek to inscribe their ideas into the discursive artefact itself. Accordingly, 
enhanced cooperation has remained a mediator "in the making", an artefact whose meaning has yet to be defined concretely. In 2012, the UN decided to consolidate the diverging interpretations and, eventually, provide a stable meaning to the ambiguous notion of enhanced cooperation. Yet, this was an undertaking that proved to be difficult. 19

\section{ORDERING THROUGH DISCOURSE: THE WORKING GROUP ON ENHANCED COOPERATION}

Following a resolution adopted by the UN General Assembly in 2012 (UN, 2012), the Working Group on Enhanced Cooperation on Public Policy Issues Pertaining to the Internet was created in 2013. Operating under the auspices of the UN Commission on Science and Technology for Development (CSTD), this multistakeholder group was mandated to develop recommendations on how to implement the WSIS mandate regarding the cooperation of stakeholders in IG. 20

\section{IDENTIFYING THE ACTORS}

Officially the WGEC comprised 42 members: 22 government representatives and five representatives from each of the currently recognised stakeholder groups (international organisations, private sector, academia/technical community and civil society). But from a perspective inspired by the ANT principle of generalised symmetry, those who acted upon the processes within the WGEC (and, accordingly, who count as actors within these processes) differed from the official members.

First, only a small number of the official government representatives actually attended the WGEC meetings or intervened in a way that impacted the group's translation processes (Kaspar, 2014; Kovacs, 2014). 21 Second, although the CSTD had decided upfront on the WGEC's official configuration, the modalities of the working procedures were altered during the group's first meeting so that observers could also attend. Moreover, video streaming and live transcripts were made available to allow members and observers to join the discussions remotely, while the last ten minutes of each session were reserved for interventions by the observers (Dickinson, Dutton, Maciel, Miloshevic, \& Radunovic, 2014, pp. 18ff). Several governmental and nongovernmental observers made use of these opportunities and actively contributed to the deliberations by drafting statements, producing room documents and reporting via Twitter. 22 Third, after its inception, the WGEC introduced another change to the procedures that altered the configuration of actors and discourses in the group as it agreed to hold public consultations via a survey on the implementation and potential operationalisation of enhanced cooperation. The 69 survey responses, resulting in over 500 pages of text, became an important working tool for the group and many of its initial debates revolved around these responses and their categorisation. The same was the case for the various documents which the group produced, with the support of some active observers, in order to consolidate and structure the survey responses.

In short, while not all group members intervened in the WGEC's deliberations, the organisational settings, the documents received and produced by the group and the ideas inscribed into their materiality left observable traces on the group's interactions. Thus these elements can be considered as acting agents which shaped the discursive production of the group and which can help to unravel the WGEC's inner workings. The merit of this approach is revealed if we follow the actors, their interactions and discursive production closely. 


\section{FOLLOW THE ACTORS AND THEIR PRACTICES}

The WGEC's mandate was to propose recommendations for implementing enhanced cooperation into existing and future IG mechanisms and procedures. Therefore, most of the actors' practices involved the translation of ideas and their inscription into draft recommendations. Between May 2013 and May 2014, the WGEC convened in Geneva four times. Since the categorisation of the survey responses could not be accomplished within the limited timeframe of the official meetings, a correspondence group was charged to complete this task in between meetings. But despite this effort, there was no mechanism to ensure that all responses categorised by the correspondence group were eventually reflected in the proposed draft recommendations. Some group members sought to consider the material input in their proposals and therefore allowed the discourses inscribed into them to act as inputs into the WGEC's deliberations. Others, by contrast, ignored the comments provided by other stakeholders and, instead, tried to inscribe discourses into the draft recommendations that were in line with their own or their government's policy agenda (Doria, 2014b; Kovacs, 2014). ${ }_{23}$ In the end, the agency that official group members had initially accorded outsiders and written texts, by inviting public comment, was subsequently reduced; these potential actors were prevented from acting upon the process of social ordering within the WGEC.

Actors' translation strategies also showed interesting variations. While all WGEC members were supposed to collaborate "on equal footing" - and in fact were treated equally by the chairman some government representatives, for instance, the Iranian delegate, made more use of their speaking rights than others (Kaspar, 2014). The most interesting translation strategies, however, were chosen by some of the observers. While they officially had a less important voice - they only had a short speaking slot in each session - they frequently approached WGEC members outside the official meetings in order to translate their comments and voice concerns. Two civil society observers established themselves as "obligatory passage points" 24 for stakeholder input by assuming the lead of the correspondence group whose goal was to consolidate the survey responses into a manageable number of items. ${ }_{25}$ In so doing, these civil society observers tried to use the variety of discourses and ideas inscribed in the various comments to influence WGEC deliberations; at the same time, they ordered and shaped these discourses and ideas, thereby changing the form and the impact they had on the WGEC's deliberation processes.

Despite various efforts by different actors, none of these endeavours eventually led to the institutionalisation of specific discourses in the form of recommendations. When the WGEC could not reach a consensus concerning some controversial issues and time was lacking for discussing others, an additional meeting was scheduled. 26 But even during the final session, divergences on a number of issues continued to persist so that the group eventually decided not to submit recommendations to the CSTD (Doria, 2014b; CSTD, 2014).

\section{RETRACING PROCESSES OF DISCURSIVE PRODUCTION}

When considering interactions within the WGEC and the difficulties it encountered from an IPA perspective - that is, by assessing the discursive exchanges and their content - it is striking that the actors' practices and positions did not appear to be primarily determined by their stakeholder categories. Like many others aspects of IG, stakeholder groups need to be considered as artefacts created in an attempt to bring order to the messy environment of global governance processes. Stakeholders are not given and stable entities but emerge through categorisations (Flyverbom, 2011, p. 38). Consequently, within the WGEC, the positions of actors did not split simply along the lines of stakeholder categories; instead, important conflicts emerged within and across stakeholder groups. As a matter of fact, when linking the conflicting 
discourses back to the actors expressing them, the WGEC's inability to reach consensus was primarily due to divergences between "discourse coalitions" formed by actors in the debates.

The concept of "discourse coalition" commonly refers to a group of actors that shares the usage of a particular discourse over a longer period of time (Hajer, 2006, p. 70; see also Schmidt, 2012, p. 101). To form a discourse coalition, actors do not need to agree on everything, coordinate their actions or share the same values or interests (which is rarely the case in multistakeholder groups involving a large number of heterogeneous actors). For Hajer, identifying discourse coalitions is the real challenge of IPA because it combines "the analysis of the discursive production of reality with the analysis of the (extradiscursive) social practices from which social constructs emerge and in which the actors that make these statements engage" (1993, p. 45). In the WGEC, we can identify at least three discourse coalitions: the first comprised actors who agreed that enhanced cooperation has not been implemented at all since no official structures have been installed for governments to formulate internet-related public policies. ${ }_{27}$ Positioned at the other extreme, the second discourse coalition was united by the claim that enhanced cooperation has been implemented in the form of multistakeholder arrangements, notably the IGF. 28 Although there were many nuances in between these two extreme positions (Kaspar, 2014), it is possible to identify a third discourse coalition around the acknowledgment that some progress had been achieved since WSIS, but that enhanced cooperation had not yet been fully realised (Aguerre, 2013; Brown, 2014). 29

By examining the arguments closely, it becomes clear that there was little compatibility between the discourses and the coalitions behind them, mainly because those actors positioning themselves at either of the two extremes were not willing to move towards a middle ground. Because these actors sought to inscribe incompatible discourses into the group's recommendations, it is not surprising that the WGEC encountered difficulties in reaching a consensus on the main issues, namely, the definitions of "enhanced cooperation" and "equal footing". As a result, after four meetings and one year of deliberation and consultation, the WGEC was not able to meet its objective and submit draft recommendations to the CSTD. During all their discursive and extra-discursive interactions, no discourse coalition was able to prevail over the others, to translate their interests and ideas more successfully than others or to institutionalise their discourses. Due to the group's pre-defined set-up, its efforts at social ordering were interrupted before any kind of power balance and discursive order -even if only an unstable and temporary one- could have been achieved.

\section{CONCLUSION: DISCOURSES, SOCIAL ORDERING AND INTERNET GOVERNANCE}

In May 2016, two years after the working group's final session, the CSTD announced the appointment of a new WGEC. Continuing with the same stakeholder composition but different individual members, it is charged with the same task as its predecessor, thereby "taking into consideration the work that has been done on this matter so far". By doing so, the CSTD has not only launched a second attempt to finally infuse the mediator, enhanced cooperation, with clearly defined meaning, but it has also acknowledged that the first effort did result in some achievement, albeit not in the form of recommendations. Although the WGEC was unable to reach consensus on which of the many interpretations of enhanced cooperation should become institutionalised through its inscription into an official UN document, it would not do the group justice to consider all of its work a failure. In fact, by following the WGEC's actors and retracing 
their discursive interactions, one recognises that, regarding some questions, the group was able to move beyond the destructive binary logic of diametrically opposed positions. In particular, concerning the wish of some governments to create a UN mechanism for IG, alternative scenarios were discussed positively. 30 Thus, in a few instances, incompatible viewpoints did give way "to a more inclusive acknowledgement of diverse views and diverse options for the way forward" (Liddicoat, 2014). This acknowledgment can be considered a discursive achievement which the successor group can now build on.

The importance of discursive achievement, although it may be merely temporary, can only be recognised through a focus on the inner workings of a multistakeholder arrangement rather than on its outcome. An approach that emphasises the role of discourse and language for policymaking and, at the same time, accounts for the multiple practices of all involved as well as the (power) relations that emerge from this interaction can thus provide new insights, as can be seen in the case of the WGEC. On the one hand, new light is shed on the performativity of multistakeholder arrangements: instead of resulting in binding or non-binding policy texts, the settings, procedures and actors in IG or other multistakeholder processes all contribute to the joint (though frequently contentious) production of discourse and a shared understanding of the issues at stake. On the other hand, studying the inner workings of multistakeholder groups provides some justification for the existence and sense of such arrangements by uncovering the discursive achievements. In fact, because of their primary function as discursive spaces for dialogue and coordination, multistakeholder processes in IG are frequently criticised as being unproductive (DeNardis, 2010, p. 3; Malcolm, 2015; Pavan, 2012, pp. 79ff); however, by meticulously retracing the production processes of particular multistakeholder arrangements and identifying what exactly they may have achieved in lieu of official policy texts, it is possible in some instances to counter this general criticism.

Overall, the production processes within multistakeholder groups can be considered as attempts at social ordering in IG because these processes generate discourses and create institutions which add to the shape and materiality of IG rules and procedures. The WGEC's deliberations had the particular characteristic that they touched the heart of the controversies which have accompanied IG processes since WSIS in 2003-05, namely, the collaboration of stakeholders and, more particularly, the role of governments in public policy-making related to the internet. Accordingly, the multistakeholder working group not only tried to attach meaning to the discursive artefact of enhanced cooperation, but also negotiated its own legitimacy as well as the influence that its various members can or should have on global IG processes. As a result, the WGEC contributed fundamentally to the governance of the internet, understood as the processes of reflexive coordination through which actors "question and redefine the rules of the game" of IG in general (Hofmann et al., 2016, p. 10). In this case, social ordering was only partially achieved because, although new joint discourses were produced, none of them was ultimately institutionalised through inscription in a consensual text or formal policy recommendation. But from an ANT perspective, "ordering is always partial and in-the-making, and all attempts to act on the world must compete with other, equally possible modes of ordering" (Flyverbom, 2011, p. 137). Opening the black box of multistakeholder arrangements through a focus on discursive production processes can provide us with valuable insights in this regard. 


\section{REFERENCES}

Aguerre, C. (2013, November 26). Enhancing Stakeholder Cooperation [Blog]. Retrieved from http://teamarin.net/2013/11/26/enhancing-stakeholder-cooperation-guest-blog/

Akrich, M. (1994). The description of technical objects. In W. E. Bijker \& J. Law (Eds.), Shaping Technology/building Society: Studies in Sociotechnical Change (pp. 205-224). Cambridge, MA: MIT Press.

Ang, P. H., \& Pang, N. (2010). Going beyond talk: Can international internet governance work? Presented at the $5^{\text {th }}$ Annual Symposium of the Global Internet Governance Academic Network (GigaNet), Vilnius, Lithuania.

Brown, D. (2014, February 24). Spotlight on Internet Governance 2014: Part Two U.N. Working Group on Enhanced Cooperation. Retrieved from

https://www.accessnow.org/blog/2014/02/24/spotlight-on-internet-governance-2014-un-work ing-group-on-enhanced-cooperat

Brown, S. D. (2002). Michel Serres: Science, Translation and the Logic of the Parasite. Theory Culture and Society, 19(3), 1-27. doi:10.1177/0263276402019003001

Callon, M. (1986). Some elements of a sociology of translation: domestication of the scallops and the fishermen of St Brieuc Bay. In J. Law (Ed.), Power, action and belief: a new sociology of knowledge? (pp. 196-223). London: Routledge.

Cressman, D. (2009). A Brief Overview of Actor-Network Theory: Punctualization, Heterogeneous Engineering \& Translation. Retrieved from

http://www.sfu.ca/cprost/docs/A\%20Brief\%20Overview\%20of\%20ANT.pdf

CSTD (2014, May), Report on CSTD Working Group on Enhanced Cooperation,

E/CN.16/2014/CRP.3. Retrieved from

http://unctad.org/meetings/en/SessionalDocuments/ecn162014crp3_en.pdf

DeNardis, L. (2010). The Emerging Field of Internet Governance (Working paper No. ID 1678343). Yale: American University. Retrieved from http://papers.ssrn.com/abstract=1678343

DeNardis, L. (2014). The Global War for Internet Governance. New Haven: Yale University Press. doi:10.12987/yale/9780300181357.001.0001

Dickinson, S., Dutton, W. H., Maciel, M. F., Miloshevic, D., \& Radunovic, V. (2014). Enhanced Cooperation in Governance (SSRN Scholarly Paper No. ID 2376807). Rochester, NY: Social Science Research Network. Retrieved from http://papers.ssrn.com/abstract=2376807

Doria, A. (2014a, March 1). Five days in the Enhanced Cooperation box. Retrieved from http://avri.doria.org/post/78199466296/five-days-in-the-enhanced-cooperation-box

Doria, A. (2014b, July 3). [Phone interview].

Epstein, D. (2011). Manufacturing Internet policy language: The inner workings of the discourse construction at the Internet Governance Forum. Presented at the TPRC 2011 - Research Conference on Communication, Information and Internet Policy, Arlington, VA: George Mason University School of Law. 

making"

Epstein, D. (2012). The Duality of Information Policy Debates: The Case of the Internet Governance Forum (PhD thesis). Cornell University, Cornell.

Epstein, D. (2013). The making of institutions of information governance: the case of the Internet Governance Forum. Journal of Information Technology, 28(2), 137-149.

http://doi.org/10.1057/jit.2013.8

Fischer, F. (2003). Reframing Public Policy: Discursive Politics and Deliberative Practices. Oxford; New York: Oxford University Press. doi:10.1093/019924264X.001.0001

Fischer, F., \& Forester, J. (Eds.). (1993). The Argumentative Turn in Policy Analysis and Planning. Durham; London: Duke University Press. doi:10.1215/9780822381815

Fischer, F., \& Gottweis, H. (Eds.). (2012). The argumentative turn revisited: public policy as communicative practice. Durham; London: Duke University Press.

doi:10.1215/9780822395362

Flyverbom, M. (2010). Hybrid networks and the global politics of the digital revolution - a practice-oriented, relational and agnostic approach. Global Networks, 10(3), 424-442. doi:10.1111/j.1471-0374.2010.00296.x

Flyverbom, M. (2011). The Power of Networks - Organizing the Global Politics of the Internet. Cheltenham: Edward Elgar.

Gasper, D., \& Apthorpe, R. (1996). Introduction: Discourse Analysis and Policy Discourse. European Journal of Development Research, 8(1), 1-15. doi:10.1080/09578819608426650

Gasser, U., Budish, R., \& West, S. M. (2015). Multistakeholder as Governance Groups: Observations from Case Studies (Berkman Center Research Publication No. No. 2015-1). Cambridge, MA: Berkman Center for Internet and Society. Retrieved from http://papers.ssrn.com/abstract $=2549270$

Hajer, M. (1993). Discourse Coalitions and the Institutionalization of Practice: The Case of Acid Rain in Britain. In F. Fischer \& J. Forester (Eds.), The Argumentative Turn in Policy Analysis and Planning (pp. 43-76). Durham; London: Duke University Press.

doi:10.1215/9780822381815-003

Hajer, M. (2002). Discourse Analysis and the Study of Policy Making. Eur Polit Sci, 2, 61-65. doi:10.1057/eps.2002.49

Hajer, M. (2005). Coalitions, Practices, and Meaning in Environmental Politics: from Acid Rain to BSE. In J. Torfing \& D. Howarth (Eds.), Discourse Theory in European Politics (pp. 297-315). Basingstoke: Palgrave Macmillan. doi:10.1057/9780230523364_13

Hajer, M. (2006). Doing Discourse Analysis: Coalitions, Practices, Meaning. In M. van den Brink \& T. Metze (Eds.), Words matter in policy and planning $\square$ : Discourse Theory and Methods in the Social Sciences (pp. 65-74). Utrecht: KNAG/Nethur.

Hofmann, J. (2016). Multi-stakeholderism in Internet governance: putting a fiction into practice. Journal of Cyber Policy, 1(1). doi:10.1080/23738871.2016.1158303

Hofmann, J., Katzenbach, C., \& Gollatz, K. (2016). Between coordination and regulation: Finding the governance in Internet governance. New Media \& Society. Advance online 

making"

publication. doi:10.1177/14614448166399

Kaspar, L. (2014, May 20). [Phone interview].

Kleinwächter, W. (2012, December 17). WCIT and Internet Governance: Harmless Resolution or Trojan Horse? [Blog]. Retrieved from

http://www.circleid.com/posts/20121217_wcit_and_internet_governance_harmless_resolutio n_or_trojan_horse/

Kleinwächter, W. (2013, November 12). Enhanced Cooperation in Internet Governance: From Mystery to Clarity? [Blog]. Retrieved from

http://www.circleid.com/posts/20131112_enhanced_cooperation_in_internet_governance_my stery_to_clarity/

Kovacs, A. (2014, July 3). [Phone interview].

Kummer, M. (2007). The debate on Internet governance: From Geneva to Tunis and beyond. Information Polity, 12(1-2), 5-13.

Kummer, M. (2012, July 2). Internet Governance: What is Enhanced Cooperation? Retrieved from

http://www.internetsociety.org/blog/2012/o7/internet-governance-what-enhanced-cooperatio $\mathrm{n}$

Latour, B. (1993). An Interview with Bruno Latour. Configurations, 1(2), 247-268.

Latour, B. (1996). On actor-network theory: A few clarifications. Soziale Welt, 47(4), 369-381.

Latour, B. (2004). On using ANT for studying information systems: a (somewhat) Socratic dialogue. In C. Avgerou, C. Ciborra, \& F. Land (Eds.), The Social Study of Information and Communication Technology: Innovation, Actors, and Contexts (pp. 62-76). Oxford; New York: Oxford University Press.

Latour, B. (2005). Reassembling the Social: An Introduction to Actor-Network-Theory. Oxford; New York: Oxford University Press.

Latour, B., \& Callon, M. (1981). Unscrewing the Big Leviathan: how actors macro-structure reality and how sociologists help them to do so. In K. Knorr-Cetina \& A. V. Cicourel (Eds.), Advances in Social Theory and Methodology: Towards and integration of Micro- and MacroSociologies of Knowledge? (pp. 277-303). London: Routledge and Kegan Paul.

Latour, B., \& Woolgar, S. (1986). Laboratory Life: The Construction of Scientific Facts (2nd edition). Princeton: Princeton University Press.

Law, J. (1992). Notes on the theory of the actor-network: Ordering, strategy, and heterogeneity. Systemic Practice and Action Research, 5(4), 379-393.

Law, J., \& Callon, M. (1988). Engineering and Sociology in a Military Aircraft Project: A Network Analysis of Technological Change. Social Problems, 35(3), 284-297.

Liddicoat, J. (2014). Working Group on Enhanced Cooperation: The next enthralling episode. APC. Retrieved from https://www.apc.org/en/blog/working-group-enhanced-cooperationnext-enthrallin 
Multistakeholder governance processes as production sites: enhanced cooperation "in the making"

Liddicoat, J., Doria, A., \& Kaspar, L. (2013). The UN Working Group on Enhanced Cooperation: Report on the second meeting. APC. Retrieved from http://www.apc.org/en/blog/un-working-group-enhanced-cooperation-report-secon

Malcolm, J. (2008). Multi-Stakeholder Governance And The Internet Governance Forum. Perth: Terminus Press.

Malcolm, Jeremy. (2015). Criteria of meaningful stakeholder inclusion in internet governance. Internet Policy Review, 4(4). doi:10.14763/2015.4.391

Marres, N. (2007). The Issues Deserve More Credit Pragmatist Contributions to the Study of Public Involvement in Controversy. Social Studies of Science, 37(5), 759-780.

doi:10.1177/0306312706077367

Mikus, M. (2009). Strategies, meanings and actor-networks: community-based biodiversity conservation and sustainable development in the Comoros (Final thesis MSc Anthropology and Development). London School of Economics, London.

Mottier, V. (2005). From Welfare to Social Exclusion: Eugenic Social Policies and the Swiss National Order. In D. Howarth \& J. Torfing (Eds.), Discourse Theory in European Politics: Identity, Policy and Governance (pp. 255-274). Hampshire and New York: Palgrave Macmillan. doi:10.1057/9780230523364_11

Mueller, M. (2012, December 18). ITU Phobia: Why WCIT was derailed. Retrieved from http://www.internetgovernance.org/2012/12/18/itu-phobia-why-wcit-was-derailed/

Münch, S. (2016). Interpretative Policy-Analyse $\square$ : eine Einführung. Wiesbaden: Springer VS. doi:https://doi.org/10.1007/978-3-658-03757-4

Musiani, F. (2015). Practice, Plurality, Performativity, and Plumbing Internet Governance Research Meets Science and Technology Studies. Science, Technology \& Human Values, 40(2), 272-286. doi:10.1177/0162243914553803

Musiani, F., Cogburn, D. L., DeNardis, L., \& Levinson, N. S. (Eds.). (2015). The Turn to Infrastructure in Internet Governance. New York, NY: Palgrave Macmillan.

Nimmo, R. (2011). Actor-network theory and methodology: social research in a more-thanhuman world. Methodological Innovations Online, 6(3), 108-119. doi:10.4256/mio.2011.010

Pavan, E. (2012). Frames and Connections in the Governance of Global Communications: A Network Study of the Internet Governance Forum. Lanham, MD: Lexington Books.

Phillips, N., Lawrence, T. B., \& Hardy, C. (2004). Discourse and Institutions. The Academy of Management Review, 29(4), 635-652.

Pickard, V. (2007). Neoliberal Visions and Revisions in Global Communications Policy From NWICO to WSIS. Journal of Communication Inquiry, 31(2), 118-139.

doi:10.1177/0196859906298162

Pohle, J. (2014). 'Mapping the WSIS+10 Review Process'. Research report on the 10-year review process of the World Summit on the Information Society. Brussels: Vrije Universiteit Brussel. Retrieved from

http://www.globalmediapolicy.net/sites/default/files/Pohle_Report\%2oWSIS+10_final.pdf 

making"

Raboy, M., \& Padovani, C. (2010). Mapping Global Media Policy: Concepts, Frameworks, Methods. Communication, Culture \& Critique, 3(2), 150-169. doi:10.1111/j.1753-

9137.2010.01064.x

Radu, R., \& Chenou, J.-M. (2014). Global Internet Policy: a Fifteen-Year Long Debate. In R. Radu, J.-M. Chenou, \& R. H. Weber (Eds.), The Evolution of Global Internet Governance: Principles and Policies in the Making (pp. 1-19). Heidelberg, New York, Dordrecht, London: Springer. doi:10.1007/978-3-642-45299-4

Raymond, M., \& DeNardis, L. (2015). Multistakeholderism: anatomy of an inchoate global institution. International Theory, 7(3), 572-616. doi:10.1017/S1752971915000081

Rioux, M., Adam, N., \& Company Pérez, B. (2014). Competing Institutional Trajectories for Global Regulation - Internet in a Fragmented World. In R. Radu, J.-M. Chenou, \& R. H. Weber (Eds.), The Evolution of Global Internet Governance: Principles and Policies in the Making (pp. 37-55). Heidelberg, New York, Dordrecht, London: Springer.

Rutland, T., \& Aylett, A. (2008). The work of policy: actor networks, governmentality, and local action on climate change in Portland, Oregon. Environment and Planning D: Society and Space, 26(4), 627-646. doi:10.1068/d6907

Schmidt, V. A. (2008). Discursive Institutionalism: The Explanatory Power of Ideas and Discourse. Annual Review of Political Science, 11(1), 303-326.

doi:10.1146/annurev.polisci.11.060606.135342

Schmidt, V. A. (2010). Taking ideas and discourse seriously: explaining change through discursive institutionalism as the fourth 'new institutionalism'. European Political Science Review, 2(1), 1-25. doi:10.1017/S175577390999021X

Schmidt, V. A. (2012). Discursive Institutionalism. Scope, Dynamics, and Philosophical Underpinnings. In F. Fischer \& H. Gottweis (Eds.), The Argumentative Turn Revisited. Public Policy as Communicative Practice (pp. 85-113). Durham; London: Duke University Press. doi:10.1215/9780822395362-004

Schmidt, V. A., \& Radaelli, C. M. (2004). Policy Change and Discourse in Europe: Conceptual and Methodological Issues. West European Politics, 27(2), 183-210.

doi:10.1080/0140238042000214874

Scott, W. R. (2008). Institutions and Organizations: Ideas and Interests. Los Angeles: SAGE Publications.

UN (2012), Resolution A/RES/67/195. United Nations General Assembly, 67th session.

Zittoun, P. (2009). Understanding Policy Change as a Discursive Problem. Journal of Comparative Policy Analysis: Research and Practice, 11(1), 65-82.

doi:10.1080/13876980802648235

\section{FOOTNOTES}

1. This idea builds on Jeanette Hofmann's recent framing of multistakeholderism as a "discursive artefact that aims to smooth contradictory and messy practices into a coherent story about collaborative transnational policymaking" (Hofmann, 2016, p. 16). 

making"

2. Borrowed from the field of natural sciences and technology, "black box" stands for a device whose complex internal workings need not be known in order to predict its outputs. STS authors use the term to refer to a material object, a situation or process which has become self-evident and obvious to the observer: "A black box contains that which no longer needs to be reconsidered, those things whose contents have become a matter of indifference" (Latour \& Callon, 1981, p. 285). For more details about the use of the concept in STS, see also Cressman (2009, p. 6).

3. Building on the Hajer's (1993, p. 45) basic definition, policy discourse can be conceptualised as a set of ideas, concepts, frames and definitions that gives meaning to a real-world phenomenon, structuring it as a concrete policy problem and proposing solutions. Because of its structuring function, the production and reproduction of discourse is perceived as an iterative process: by addressing the problem and its potential solutions in official policy texts, the worldview behind the discourse is stabilised and reproduced in common policy thinking. For an overview on the different understandings of the term "discourse" in relation to policy and policymaking, see Gasper \& Apthorpe (1996, pp. 2ff).

4. Interpretative policy analysis is also referred to as argumentative or deliberative policy analysis. Although there are small conceptual and methodological differences between the different approaches, this paper subsumes them all under the most commonly used category of "interpretative" approaches to policy analysis (for more details, see Münch, 2016, pp. 3ff).

5. A notable exception is Marek Mikus' work on strategies, meanings and actor-networks in sustainable development (2009). ANT has also been used to study issue formation and discursive processes of public involvement in participatory democracy. For examples and criticism, see Marres (2007, pp. 361ff).

6. Initiated in the 1980 s by a group of French sociologists, most of ANT's notions and methodological tools were developed out of these scholars' empirical case studies in scientific laboratories. Over the years, ANT has become a popular approach for observing the creation of knowledge in science and technology as well as processes of social ordering and the creation of meaning in many different contexts.

7. ANT's originators borrowed the term "translation" from the French philosopher Michel Serres, in whose work "translation appears as the process of making connections, of forging a passage between two domains, or simply as establishing communication" (Brown, 2002).

8. Since the term "multistakeholder" was coined in the 1990s, its characteristics have been defined in a multitude of ways. For an overview on the use of the multistakeholder concept within and outside of internet governance research, see also Hofmann (2016).

9. There are many other ways in which ANT's principle of "generalised symmetry" impacts the analysis of multistakeholder governance processes. Mikkel Flyverbom, for instance, regards multistakeholder arrangements as "contingent assemblages under constant (re)construction", meaning a hybrid network of heterogeneous actors ranging from technologies to badges, emails, activists and many more actors (2011, p. 8). A full assessment of the potential implications of ANT's enlarged understanding of actors would go beyond the scope of this paper.

10. The long held disagreement revolves around the interpretation of article $72(\mathrm{~g})$ of the Tunis Agenda, which requests the IGF to "identify emerging issues, [...] and, where appropriate, make recommendations"; this, in turn, can be understood as a call for the production of outcome 

making"

documents. For more details about this debate, see Malcolm (2008, pp. 355ff).

11. Due to its focus on dialogue rather than output, the IGF has often been described as a "talk shop" (Ang \& Pang, 2010, p. 1). Many scholars and practitioners emphasise the discrepancy between IG discourse and praxis since most studies on multistakeholderism in IG centre on who contributes to discussions rather than who contributes to the actual practices of IG (Raymond \& DeNardis, 2015, p. 588).

12. If a successful translation starts to structure the discourse of a larger group of actors, Maarten Hajer speaks of "discourse structuration", which "occurs when a discourse starts to dominate the way a given social unit [...] conceptualizes the world" (Hajer, 2005, p. 303).

13. The concept of "inscription" was first used by ANT scholar Madeleine Akrich to describe how engineers, inventors, manufacturers or designers "inscribe" their vision into the design of an object or the materiality of a technical artefact (Akrich, 1994).

14. In institutional theory, institutionalisation is considered the process through which institutions are (re)produced. The idea that institutions are constructed and transformed through discourse is developed in great detail in Phillips, Lawrence, \& Hardy (2004) and Schmidt (2010).

15. This self-reinforcing function of discourses and institutions has been described frequently by organisational theory and neo-institutionalism (for instance, Schmidt \& Radaelli, 2004; Scott, 2008, p. 149).

16. For a more detailed description of the inner workings and discursive exchanges of the WGEC and its relation to the ten-year review of WSIS, see Pohle (2014, pp. 25ff) and the dedicated mapping section on the Global Media Policy Platform.

17. Concerning the development of IG as a new field of political action during WSIS, it would be interesting to retrace the process through which the concept of enhanced cooperation was inscribed into the Tunis Agenda. But since the WSIS outcome documents were only negotiated by governments and not through a multistakeholder process, such an analysis would not comply with the conceptual objective of this research paper.

18. In the years following WSIS, the discrepancy between these two supposedly irreconcilable positions has not been overcome, as recurrent disputes on the issue in international forums like ITU's 2012 World Conference on International Telecommunication (WCIT) have shown (Kleinwächter, 2012; Mueller, 2012).

19. For more details about several other attempts since 2006, in which the UN sought agreement on the controversial topic of enhanced cooperation, see Aguerre (2013).

20. Official details and meeting summaries of the WGEC are available on the UNCTAD website. The creation of the WGEC was preceded by a one-day open consultation, organised by the CSTD on 18 May 2012, and a long and controversial discussion during the CSTD session in May 2012, which ended with the proposal to mandate a working group (Kummer, 2012).

21. According to observers, the most active government representatives were from the USA, Sweden, Nigeria, Japan, Iran, Russia, Saudi Arabia and India (Kaspar, 2014).

22. The most active observers from civil society and the technical community were Anja Kovacs, 

making"

Samantha Dickinson, Matthew Shears, Joana Veron, Lea Kasper, Deborah Brown and Richard Hill (Doria, 2014b; Liddicoat, 2014). In addition, there were observers from governments not represented in the group, such as the UK and Canada.

23. The impact of different governments on the group's work also depended on whether they sent representatives from their capitals, who were experts on the topics discussed, or simply relied on their official delegates in Geneva, who did not necessarily have the same specific expertise and could, therefore, not influence the deliberations in the same way (Kaspar, 2014).

24. The concept of "obligatory passage points" (OPP) was introduced into ANT literature by Michel Callon, who describes it as one of different moments of translation. To become an OPP, an actor has to create a situation in which all actors have to interact with him in order to achieve their goal. As a result, the actor is in a privileged position as he can seek to translate his interests through these interactions (Callon, 1986).

25. The two observers who did most of the correspondence group's work were Lea Kaspar and Samantha Dickinson, while two group members, Joy Liddicoat and Phil Rushton, served as its official chairs. The correspondence group was open to everyone who had responded to a public call for interest. In addition, all members of the WGEC were automatically members of the group, although most of them did not engage in the work (Doria, 2014b; Kaspar, 2014).

26. For details about the deliberations during the WGEC's third meeting and the difficulties encountered, see Doria (2014a), Liddicoat (2014) and Liddicoat, Doria, \& Kaspar (2013).

27. This position was, for instance, taken by the delegate from Saudi Arabia but also by other actors, including from civil society.

28. This was, for instance, the position of the delegates from Japan and Finland but also of representatives from the technical community and from civil society.

29. This position was expressed, for example, by the delegates from Brazil but also by the civil society representative from the Association for Progressive Communications (APC).

30. One of the options considered by the WGEC was the creation of a platform, possibly under the auspices of the CSTD, through which governments could share information and resources (Kovacs, 2014). 